\title{
BUILDING BUSINESS CONTRIBUTIONS FOR THE 2020 GLOBAL NUTRITION SUMMIT
}

SUMMARY REPORT OF A WORKSHOP HELD 25 - 26 JUNE 2019, THE HAGUE, THE NETHERLANDS

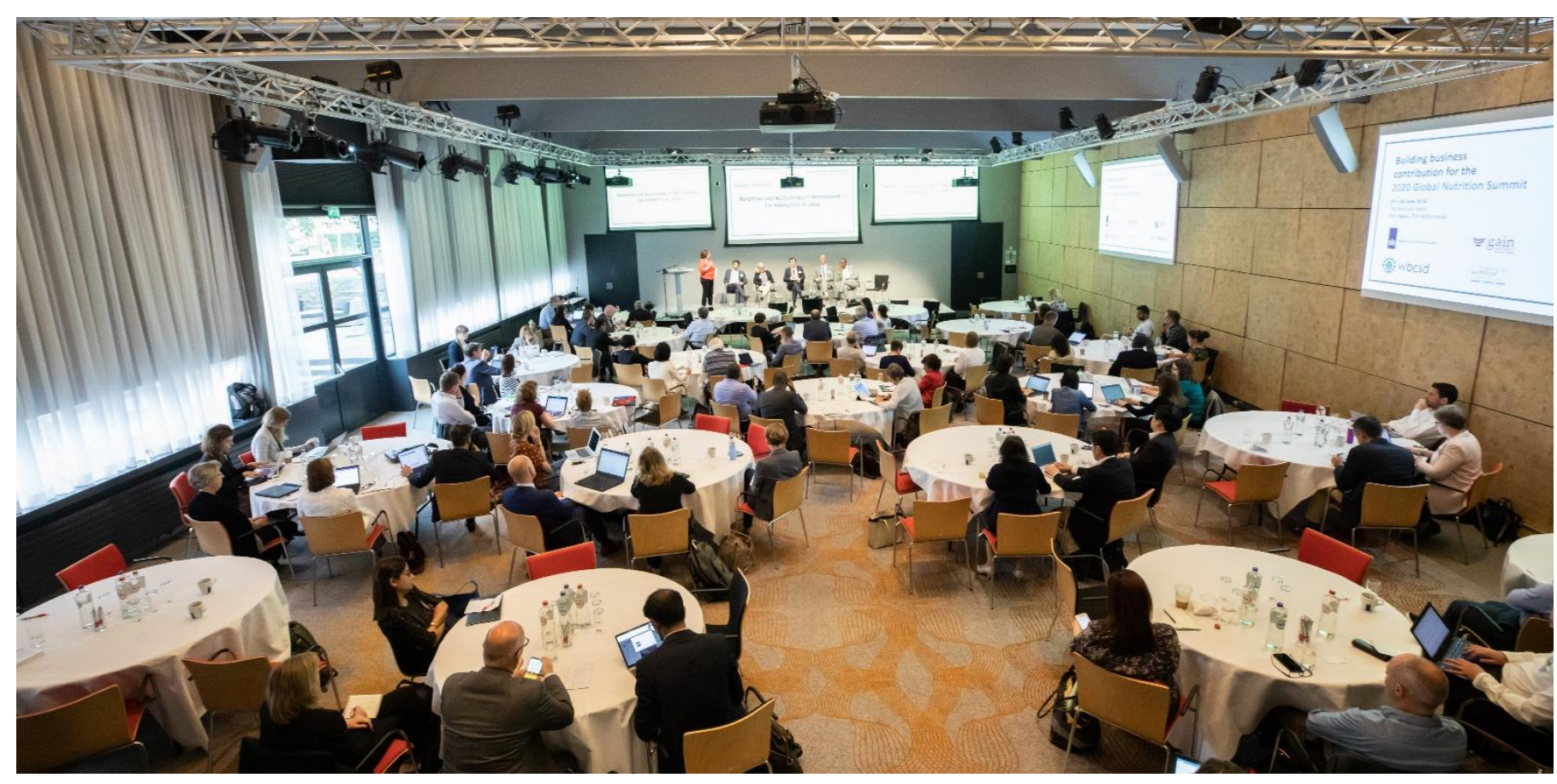

GAIN Convening Paper Series $n^{\circ 7}$

October, 2019 


\section{ABOUT GAIN}

The Global Alliance for Improved Nutrition (GAIN) is a Swiss-based foundation launched at the UN in 2002 to tackle the human suffering caused by malnutrition. Working with governments, businesses and civil society, we aim to transform food systems so that they deliver more nutritious food for all people, especially the most vulnerable.

\section{Recommended citation:}

Building Business Contribution for the 2020 Global Nutrition Summit: Summary Report. Global Alliance for Improved Nutrition (GAIN). Convening Paper Series \#7. Geneva, Switzerland, 2019. DOI:

https://doi.org/10.36072/cp.7

\section{(C) The Global Alliance for Improved Nutrition (GAIN)}

This work is available under the Creative Commons Attribution-Non-Commercial-Share Alike 4.0 IGO licence (CC BY-NC-SA 4.0 IGO; https://creativecommons.org/licenses/by-nc-sa/4.0/). Under the terms of this licence, you may copy, redistribute and adapt the work for non-commercial purposes, provided the work is appropriately cited, as indicated below. In any use of this work, there should be no suggestion that GAIN endorses any specific organisation, products or services. The use of the GAIN logo is not permitted. If you adapt the work, then you must license your work under the same or equivalent Creative Commons license. The contributions of third parties do not necessarily represent the view or opinion of GAIN. All photographs included in this document have been taken with consent for use in publications.

\section{Acknowledgements}

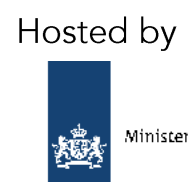

Organised by
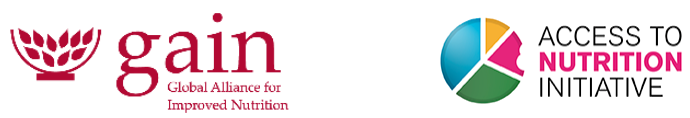

Supporting partners

\section{wbcsd}

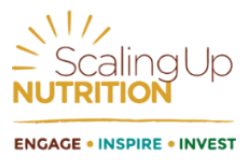

\section{米 NWGN}

\section{GAIN CONVENING PAPER SERIES}

The GAIN Convening Paper Series brings together proceedings and reports from events that have been convened or co-convened by GAIN.

The Global Alliance for Improved Nutrition (GAIN)

Rue de Varembé 7

1002 Geneva

Switzerland

T: +41227491850

E: info@gainhealth.org

www.gainhealth.org 


\section{PREFACE}

The Hague conference on Building Business Contribution for the 2020 Global Nutrition Summit aimed to set a course on broad principles and ideas for specific contributions by business and other stakeholders working together in support of the Summit. This summary report sets out the background, main findings, and recommendations; the agenda and participant list are included in the annex.

We are grateful for the support of the World Business Council for Sustainable Development (WBCSD) and its sister business organisations from the private sector who were important partners in preparing this conference: the International Food and Beverage Alliance (IFBA), Consumer Goods Forum (CGF), Scaling Up Nutrition (SUN) Business Network (SBN), US Council for International Business (USCIB), and Food Industry Asia (FIA). Governments, civil society, and the non-profit sector each played a constructive role in building this joint effort.

One hundred and fifty diverse representatives from government, civil society, the non-profit sector, and business participated in the meeting. Sixty company and private-sector representatives and six leading business associations contributed. Malnutrition is an injustice, and everyone attending the meeting has a unique contribution to make to righting this. We are much stronger when we remember this and when we work together. The conference demonstrated that spirit and produced practical recommendations for the Summit organisers.

We would like to thank the Government of Japan for its support and participation. We would also like to thank the Government of the Netherlands and the senior leadership of the Ministry of Foreign Affairs and the Ministry of Agriculture for hosting this event and the many Dutch structures, such as the Netherlands Working Group on International Nutrition, as well as the leading Dutch companies and institutions who addressed the group. Every country could learn much from how the Dutch undertake food system work, and we are very grateful to our Dutch colleagues for their support.

Lawrence Haddad (Global Alliance for Improved Nutrition - GAIN) \& Inge Kauer (Access to Nutrition Initiative - ATNI)

\section{Conference Co-Chairs}




\section{INTRODUCTION}

The Japan Global Nutrition Summit 2020 will be a follow up to the Nutrition for Growth (N4G) Summit held in London in 2013, which helped elevate nutrition to be a major component of the Sustainable Development Goals (SDGs). The London N4G mainly concentrated on tackling undernutrition (stunting, wasting, and associated child mortality), with a major focus on a child's first 1,000 days of life and how governments and donors could take action. At the summit, 110 stakeholders made commitments of over USD 4 billion to tackle undernutrition, and USD 19 billion was committed in complementary nutritionsensitive investments between 2013 and 2020. Business was not a leading player, although the Summit was hosted by Unilever. The London N4G commitments end in 2020, and the Japan Summit is the point at which new commitments for the next decade will be made.

The context and understanding of malnutrition have changed significantly over the seven years since the London N4G. The goals of the 2020 Summit are to position nutrition as an essential driver of sustainable development and to secure new and refreshed policy and financial commitments from governments, civil society, the private sector, donor agencies, and the UN to act on malnutrition in all its forms. Five thematic groups were set up to provide advice to the Government of Japan on the agenda and goals over the summer of 2019. The five goals are to:

1. Make nutrition integral to universal health coverage for sustainable development;

2. Build food systems that promote healthy diets and nutrition, ensure producers' livelihoods, and are climate-smart;

3. Address malnutrition effectively in fragile and conflict-affected contexts;

4. Promote data-driven accountability;

5. Secure new investment and drive innovation in nutrition financing.

The Building Business Contributions for the 2020 Global Nutrition Summit conference in The Hague took place as part of Workstream 2 on food systems, which is coordinated by the UK Department for International Development (DFID) and the UN Food and Agriculture Organization (FAO). The Access to Nutrition Foundation (ATNI) and the Global Alliance for Improved Nutrition (GAIN) were asked by the workstream coordinators to lead consultations on building business contributions as part of this work.

The Government of the Netherlands agreed to host the conference, and the agenda was co-developed with input from government, donors, and civil society. The agenda was planned with the SUN Movement, the Netherlands Working Group on International Nutrition (NWGN), and the WBCSD, as well as GAIN, ATNI, the SUN Business Network, and the Ministry of Foreign Affairs of the Netherlands. The Government of Japan opened and closed the conference.

The conference was motivated by the fact that even the poorest obtain most of their food by buying it in markets, making business fundamental to food systems for every country and every sector of society. Engagement between public and private structures around making food systems more supportive of nutrition is weak, with the two sides barely knowing each other; there are also some 'flash points' between the public and private sectors.

Without business buy-in, however, it will be impossible to effect real change in food systems, which will require clear, transparent, and universally applicable principles of engagement, both in general and for the way the Japan Summit process is conducted:

- Solutions to malnutrition cannot be achieved without coordinated action by governments, businesses, and civil society. Therefore, we need to talk with purpose to find mutually reinforcing joint commitments and set these out; 
- We must harness established global standards. This means we need to address challenging areas for some businesses, such as compliance with marketing standards, the International Code of Marketing of Breastmilk Substitutes, and labour standards;

- We recognise that it is the duty of governments to set and enforce policies and standards and that all other stakeholders should be free to express their views transparently and respect this;

- Commitments need to be proportionate to solutions: we want to avoid the situation where institutions can 'cherry pick' easy commitments but ignore or exacerbate problems in other areas;

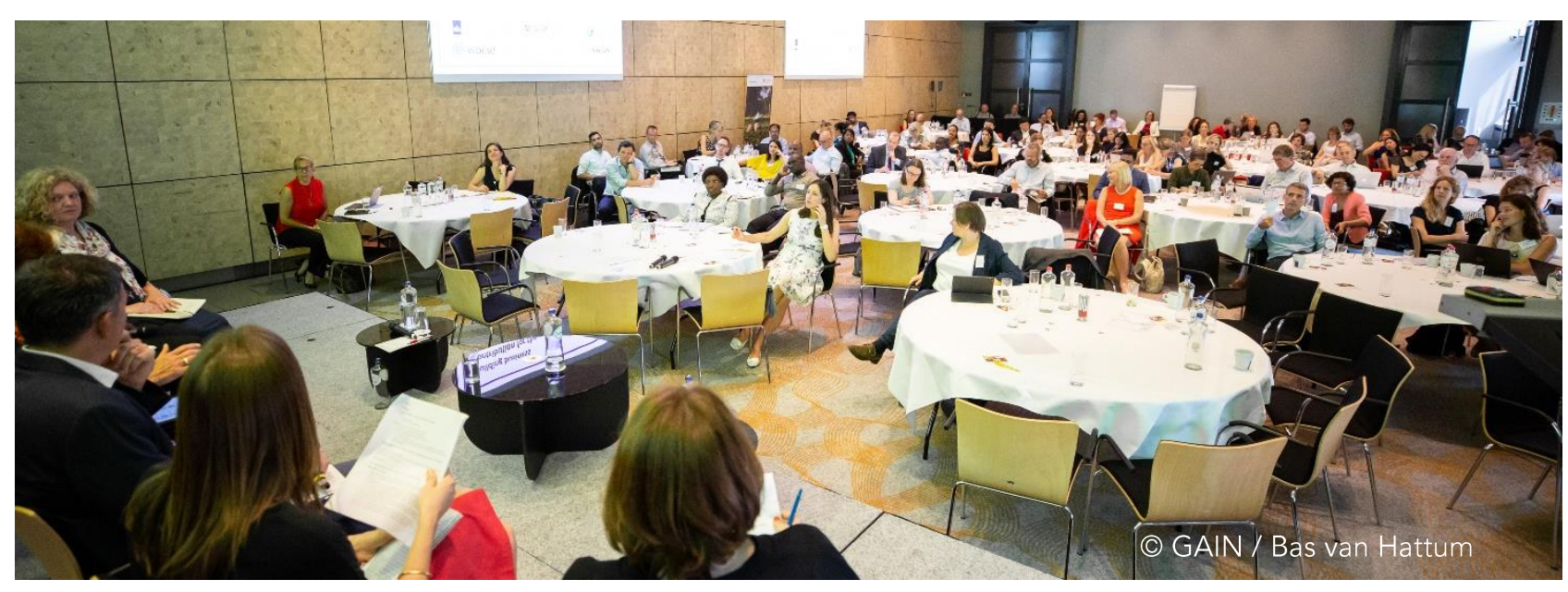

These principles of engagement underlie a set of specific actions to be taken in the run-up to the Global Nutrition Summit in Japan 2020:

- Develop contribution areas for the Summit:

- Prioritise actions that businesses can take to accelerate sustainable progress towards achieving the 2030 nutrition goals;

- Identify complementary actions that governments and civil society organisations need to take to enable those business actions;

- Begin to discuss the nature of specific contributions needed from businesses, governments, and civil society organisations to put these actions into effect;

- Agree on principles of engagement between businesses, governments, and civil society organisations to allow these commitments to be developed and implemented for the maximum positive impact on nutrition;

- Work towards a more streamlined and effective reporting and accountability system for business commitments in the GNS Compact;

- Provide advice and recommendations to the N4G summit organisers on the above.

\section{CONFERENCE CONCLUSIONS: SUMMARY OF THE CO-CHAIRS}

Participants included 145 diverse representatives from government, civil society, the non-profit sector, and business. In addition, 60 company and private-sector representatives and six leading business associations contributed. In their statements, the governments of the Netherlands, the UK and Japan emphasised the critical role food systems play in tackling interlinked challenges from malnutrition to climate change and environmental sustainability. It was stated that, "business is at the core of these systems, and good nutrition is instrumental to the achievement of at least 12 of the 17 SDGs." The Director General of the FAO, Dr Graziano da Silva, put it starkly that we need a radical transformation and this can only be achieved by strategic alliances. In food, business is a core player. The Government of Japan also underlined the strong link between achieving universal health coverage and enabling food 
systems to deliver better diets for all. The evidence for causal links between poor diets and poor health outcomes is now overwhelming, and we commend Japan for making this a major theme of the Summit.

It was recognised that the Summit, to be held in Japan in 2020, is a unique opportunity, as it marks the end date for the completion of commitments made at the original Nutrition for Growth Summit in 2013 and leaves ten years to deliver on the SDGs in 2030. The following sub-sections summarise the main themes of the discussion at the conference.

\section{The changing agenda}

We are witnessing a period of dramatic change in thinking about how to approach the SDGs, especially given the backdrop of a climate and environmental sustainability crisis. Malnutrition affects a third of all people globally and still accounts for $45 \%$ of all child deaths under five years of age. Food systems are seen to be increasingly more instrumental to overcoming global challenges, with many SDGs linked to nutrition and in danger of being undermined. There is a plethora of complementary and parallel efforts to shift policies at the global level. The meeting identified the main platforms to which food systems work should connect and that our work can make a contribution to rethinking food systems; this can be highlighted at the 2020 Climate Summit and the proposed 2021 Food Systems Summit. It was helpful to have the Food and Land Use Coalition (FOLU), EAT, and the World Economic Forum (WEF) present to help link the specific focus of the group to wider system challenges; they will be important partners in the effort to prepare for Japan over the next 12 months.

Business participants described a fast-paced environment in which many consumers, and increasingly young consumers, are demanding change in future food systems to provide healthier, tasty diets that are also better for the planet. We heard many examples of individual actions being taken related to supporting the workforce, launching new products, and sustainability. At the same time, however, for many consumers in all countries the quality of their diet is falling, due partially to the high costs of many nutritious foods and the low nutritional quality of many widely available food products.

Future food systems are therefore ready for remaking. The Japan Summit should help address some 'frontier issues' identified and the lack of working platforms between the public and private sectors to create new business models that support public health and sustainable food systems. The best way to raise standards and achieve impact is to forge ahead with innovators and leaders across the sector, without waiting for the slowest.

\section{Strengthening business contributions and commitments to the 2020 Summit}

We believe the Summit needs to make space for diverse types of commitments capable of addressing the systemic nature of the challenges of food systems. This requires collective action plans that encourage the support of individual companies and governments. We therefore recommend that Tokyo commitments, wherever possible, are bundled into subject areas with joint and mutually reinforcing plans for delivery and assessment, against which individual commitments can be made. These can be aligned with the Summit thematic working groups. Business commitments should be set out and be accompanied by complementary enabling commitments from governments, civil society organisations, and development partners that are required to achieve the intended impact. All commitments must be Specific, Measurable, Achievable, Realistic and Timely (SMART).

The private-sector organisations present have indicated that they are ready to work together to develop and help channel business contributions to the Japan Summit. As noted, this means building new coalitions with government, donor, and civil society partners. The Paris Lima Climate Action Agenda was mentioned as a good model to galvanise non-state actors in this type of planning. Business associations have a unique role to play to build these frameworks for collective action. We will recommend that 
business is part of the Summit planning process in line with the principles of engagement set by the organisers.

We, as organisers of this event, and the businesses present, are ready to help the five working groups for the Summit (on food systems, investment, fragile states, universal health coverage, and data/accountability) to bring in the resources and ideas from this conference. We identified candidate topics, where such ambitious and innovative commitments and action plans could be developed over the next 12 months for agreement at Tokyo. These are not exclusive but showed models of how to develop these contributions.

For example, the discussion on acceleration of product reformulation showed promise in terms of discussion goals and setting a framework for joint action. The WBCSD's white paper on plant-and animalsourced foods and the planned review of the state of reformulation create a promising framework for new collective action.

Detailed discussions on marketing safeguards for children identified some common areas of focus, expanding to all channels, including: digital, all settings where children typically gather, age limits, the importance of independent audits, and nutrient profiling. The Olympics are a unique opportunity to showcase what responsible marketing and education on healthy options could look like. Partners are challenged to show what business can contribute. On improving diets via animal-sourced foods and plant-based foods, this was identified as an important area to explore action. Strategies to diversity and expand new nutritious food sources and recycle food waste/loss into the food system is a high priority. Workforce nutrition will be looking at setting up some norms for all stakeholders and innovative actions supporting businesses to share their models of implementation.

New finance and investment models will focus on two areas: firstly setting goals for expanding new blended finance for small and medium-sized enterprises (SMEs) in food systems and secondly linking the work of the WBCSD, the Food Systems Dialogues, and ATNF to develop an international investor coalition, with the support of business platforms and governments that pledge support to a set of investor expectations on nutrition and health. We will explore whether investors could ask food and beverage companies to commit to this set and announce it at the Summit in Tokyo.

Fortification and biofortification are great examples of highly effective public/private collaboration to help end malnutrition. The unfinished agenda needs to be emphasised in Tokyo. Government leadership is critical to get regulation right, with everyone on board and standards monitored and enforced. Companies can fortify, but governments need to enforce. Communication to consumers is vital.

The summary outcomes and recommendations reported by the working sessions in the seven areas are:

1. Reformulation: the discussion on acceleration of reformulation of products showed promise in terms of discussion goals and setting a framework for joint action. The WBCSD's white paper on plant- and animal-sourced foods and the planned review of the state of reformulation create a promising framework for renewed collective action. Recommendations:

- Government nutrient profiling models are needed at the national and regional levels to identify foods that promote health and nutrition. Take the opportunity to fortify.

2. Animal-sourced foods: Improving diets via animal-sourced foods and plant-based foods was identified as an important area to explore action. Strategies to diversify and expand new nutritious food sources and recycle food waste/loss into the food system is a high priority. Recommendations: 
- Recommendations by the World Health Organization (WHO) and FAO need to be aligned. Diversification of animal sources is needed. Do more to recycle animal-sourced food loss and food waste safely back into the system.

3. Fruits and vegetables: this session highlighted the importance of value chain development, demand creation, and the informal sector. Recommendations:

- Public procurement targets, improved infrastructure, more demand creation, more public research and development for fruits and vegetables (F\&V), and more financing for F\&V operators in value chains to increase availability and affordability.

4. Marketing to children: Marketing safeguards for children were discussed, and some common areas of focus were identified. The session emphasised the need to protect all children of all ages from unhealthy food marketing (i.e., limit children's exposure to marketing) and the importance of crossborder and legally enforceable regulations. As part of that, there were strong calls to establish specific and tangible commitments to ban advertising of unhealthy foods during the Olympics. Participants also raised the need for commitments that would not just reduce/limit harm but also incentivise marketing of healthy options. Recommendations:

- More comprehensive regulation that covers all channels, all forms/appeals and places where children gather. With a specific focus on digital as a medium that has a clear fit with children but is still strongly developing, therefore monitoring is challenging.

- Need to comply with regulations on marketing of food and non-alcoholic beverages to children and work with governments to reinforce the effectiveness of these regulations.

- Work with governments to establish and enforce appropriate standards and regulations for promoting healthy food.

- Remain accountable to governments in complying with human rights requirements for carrying out food business to positively impact improved nutritional outcomes.

- Where applicable, regional WHO nutrient profiles and national guidelines need to be used as guidance to determine which products can be marketed to children.

- Acknowledgment of children up to 18 and protection of all children.

- Discussion to define SMART targets to shift marketing budgets towards the promotion of healthier products.

5. Workforce: this group conferred about setting up some norms for all stakeholders and innovative actions supporting businesses to share their models of implementation. Recommendations:

- Use ATNI categories, work with companies throughout the value chain, monitor the micronutrient status of employees, develop business to business (B2B) learning labs on how to do workforce nutrition, and make it easy for women to breastfeed on site.

- Extend workforce nutrition policies to incorporate not just their own company workforce, but also workplaces across the supply chains, including the creation of family-friendly workplaces (e.g., by providing adequate space, time and support for breastfeeding mothers).

6. Fortification: Fortification and biofortification are great examples of highly effective public/private collaboration for an effective tool to help end malnutrition. The unfinished agenda needs to be emphasised in Tokyo. Government leadership is critical to get this regulation right, with everyone on board and standards monitored and enforced. Companies can fortify, but governments need to enforce. Communication to consumers is vital. Recommendations:

- There is an unfinished agenda, get rid of tariffs and taxes on premixes, harmonise regulations and standards across borders within trading regions, scale up biofortification, south-south cooperation to bring SMEs up to capacity, guidance needed on where to draw the line on fortifying less healthy foods. 
7. Financing of nutritious foods: need governments and donors to provide working capital for nutritious foods financing funds, need metrics to ensure foods are nutritious and that impact is occurring, need to convince existing funds to pay more attention to nutrition (currently low priority). Develop an investor coalition, via business platforms. Recommendations:

- New finance and investment models will focus on two areas: setting goals for expanding new blended finance for SMEs in food systems and linking the work of WBCSD, the Food Systems Dialogues, GAIN, and ATNF to develop an international investor coalition, with the support of business platforms and governments that pledge support to a set of investor expectations on nutrition and health. We will explore whether investors could ask food and beverage companies to commit to this set and announce it at the Summit in Tokyo.

We note that there may be other topic areas that could be added via the planning process.

\section{Principles}

The SUN Movement Principles of Engagement were welcomed as a good guide to multi-stakeholder cooperation, with their emphasis on transparency, inclusiveness, mutual accountability, and collaboration towards common objectives. We all want to be guided by the goal of doing more good and doing no harm. In this regard, it is important to apply agreed global health standards. Protection of breastfeeding is especially important, as enshrined in the Breastmilk Substitutes Marketing Code. We hope that the Japan Summit will be a platform to bring forward clear company commitments to comply with the Code.

To ensure that the Japan 2020 Global Nutrition Summit delivers credible and well-supported outcomes for nutrition, the Summit itself will require principles of engagement. These should respect the unique roles of governments, business, and civil society organisations. We are confident that the process under way to finalise these will succeed.

\section{Accountability and reporting}

We set out specific ideas for how to streamline accountability and reporting arrangements for the Summit, building on existing expertise and gaps in the current accountability mechanisms. This process involves ATNF, World Benchmarking Alliance, GAIN, CGF, WBCSD, IFBA, the Food Climate Research Network (FCRN), and the SBN and aims to bring further clarity on business impact on nutrition, avoid reporting 'fatigue' from businesses, and generate learning and trust across the public and private sectors. It will support the Global Nutrition Report reporting. 


\section{ANNEXES}

\section{PROGRAMME}

\section{DAY ONE}

Welcome and opening

Moderator: Lawrence Haddad, Executive Director, GAIN

Speakers: Birgitta Tazelaar, Deputy Director-General for International Cooperation, Ministry of Foreign Affairs, Netherlands; Video Message by Jose Graziano da Silva, Director General, FAO introduced by Anna Lartey, Director for Nutrition at FAO; Yoshiko Kijima, Minister of the Embassy of Japan in the Netherlands; Gerda Verburg, Coordinator, Scaling Up Nutrition Movement; Rocco Renaldi, Secretary General, International Food and Beverage Alliance; Diane Holdorf, Managing Director, World Business Council for Sustainable Development; Tobias Wasmuht, CEO, SPAR International; Shawn K Baker, Director of Nutrition, Global Development Program, Bill \& Melinda Gates Foundation.

Setting the scene: London 2013 - Japan 2020 - SDGs 2030

Moderator: Lawrence Haddad, Executive Director, GAIN

Speakers: Darren Welch, Director of Policy, DFID; Leonard Mizzi, Head of Unit, DG DEVCO, European Commission; Fokko Wientjes, Vice-President, Nutrition, Emerging Markets, Royal DSM and member SUN Business Network; Melissa Pinfield, Director, Food and Land Use Coalition (FOLU); Dr. Sudhvir Singh, Director of Policy, EAT

How does business see nutrition challenges and opportunities in context of Japan, and what does it need from other stakeholders, especially government and civil society, to deliver impact?

Keynote address by Louise O. Fresco, President, Wageningen University \& Research

Moderator: Inge Kauer, Executive Director, ATNI

Speakers: Steven Bartholomeusz, Policy Director, Food Industry Asia; Abdul Cauio Sualehe, Technical Director, Miruku Agro-Industria, Mozambique; Sean de Cleene, Head of Food System Initiative and Member of the Executive Committee, World Economic Forum; Chavanne Hanson, Food Choice Architecture and Nutrition Manager, Google; Isabelle Grosmaitre, Alimentation Catalyst, DANONE, Co-Chair Health \& Wellness, Consumer Goods Forum

\section{Working sessions}

(See recommendations of the Priority areas or (re)new(ed) action plans \& commitments on key areas for nutrition action towards 2030 in Concluding statement from the co-chairs)

Working better together

Moderator: Inge Kauer, Executive Director, ATNI

Speakers: Gerda Verburg, Coordinator, Scaling Up Nutrition Movement; Steven Bartholomeusz, Policy Director, Food Industry Asia; Alison Cairns, Director, Food Systems Transformation, World Business 
Council for Sustainable Development; Dr Chris Osa Isokpunwu, Head of Nutrition for the Federal Ministry of Health, Nigeria; Katherine Richards, Head of Hunger and Nutrition, Save the Children, UK

Closing remarks of day one

Cornelia Richter, Vice-President of IFAD and Chair, UN Standing Committee on Nutrition

Aldrik Gierveld, Deputy Director-General Agriculture and Nature, Director Department of European International Agro-Economic Policies, Ministry of Agriculture, Nature and Food Quality, Netherlands

\section{DAY TWO}

Opening Remarks

Carola van Rijnsoever, Director of Inclusive Green Growth Department and Ambassador for Sustainable Development, Ministry of Foreign Affairs, Netherlands

Reporting and accountability mechanisms: Towards a New Framework: Streamlining reporting Moderator: Lawrence Haddad, Executive Director, GAIN

Speakers: Ido Verhagen, World Benchmarking Alliance; Mark Wijne, Access to Nutrition Foundation; Laurene Aubert, Senior Associate, GAIN/SBN

Reporting and accountability mechanisms two: The perspective of users

Moderator: Inge Kauer, Executive Director, ATNI

Speakers: Japo Ouwerkerk, Global Government Affairs, PepsiCo; Lina Mahy, Technical Officer, Office of the Director World Health Organization; Rocco Renaldi, Secretary General, International Food and Beverage Alliance; Peter van der Werf, Director, Active Ownership, Robeco; Dr Chris Osa Isokpunwu, Head of Nutrition for the Federal Ministry of Health, Nigeria.

Report backs: Priority areas or (re)new(ed) action plans \& commitments on key areas for nutrition action towards 2030

\section{Concluding Session}

Moderators: Inge Kauer and Lawrence Haddad

Speakers: Paul van de Logt, Head Food and Nutrition Security Team, Inclusive Green Growth Department, Ministry of Foreign Affairs; Gerda Verburg, Coordinator, Scaling Up Nutrition Movement; Rocco Renaldi, Secretary General, International Food and Beverage Alliance; Alison Cairns, World Business Council for Sustainable Development; Shawn Baker, Director of the Nutrition team, Bill and Melinda Gates Foundation; Luisa Volpe, Head of Policy Development, World Farmers' Organization; Md Ruhul Amin Talukder, Joint Secretary, Ministry of Agriculture, Government of Bangladesh; Isabelle Grosmaitre, Alimentation Catalyst, DANONE, CoChair Health \& Wellness, Consumer Goods Forum; Yoshiko Kijima, Minister of the Embassy of Japan in the Netherlands. 
PARTICIPANTS

\begin{tabular}{|c|c|c|}
\hline Name & Job title & Organisation \\
\hline Abdallah Nasibu Hamadi & General Manager - Kilima Operation Unit & Unilever Tea Tanzania Limited \\
\hline Abdul Cauio Sualehe & Technical Director & Miruku Agro-Industria \\
\hline Adebimpe Adebiyi & Federal Ministry of Health Director & Family Health, Nigeria \\
\hline Agnes Martin & Health \& Diet Advocacy Director & Danone \\
\hline Ahmed Mobark Ahmed & General manager & Samil indutrial co. \\
\hline Ajai Puri & Non-Executive Director & $\begin{array}{l}\text { Tate and Lyle PLC, Firmenich SA and } \\
\text { Britannia Industries Limited, India }\end{array}$ \\
\hline Aldrik Gierveld & Deputy Director General Agro & $\begin{array}{l}\text { Ministry of Agriculture, Nature and Fodod } \\
\text { Quality }\end{array}$ \\
\hline Alison Cairns & Director, Food Systems Transformation & WBCSD \\
\hline Alison Middleton & Coordinator Food Security & $\begin{array}{l}\text { Department of Agriculture, Nature and } \\
\text { Food Quality }\end{array}$ \\
\hline Amit Kataria & Senior Vice President & Hexagon Nutrition \\
\hline Andrea Kelly & $\begin{array}{l}\text { Sr. Analyst, Health \& Wellness Policy \& } \\
\text { Partnerships }\end{array}$ & PepsiCo \\
\hline Andreas Bluthner & Director Food-Fortification \& Partnerships & BASF SE \\
\hline Andris Piebalgs & Professor & EUI \\
\hline Andy Rigsby & Senior Program Officer & Bill \& Melinda Gates Foundation \\
\hline Anna Lartey & $\begin{array}{l}\text { Director, Nutrition and Food Systems } \\
\text { Division }\end{array}$ & FAO \\
\hline Annegre de Roos & Senior Advisor Food and Nutrition Security & Save the Children Netherlands \\
\hline Anouk de Vries & Trainee Food and Nutrition Security & Ministry of Foreign Affairs, NL \\
\hline Ans Eilander & & Unilever \\
\hline Arun Baral & CEO & HarvestPlus \\
\hline Astrid Mastenbroek & $\begin{array}{l}\text { Senior policy officer Food and nutrition } \\
\text { security }\end{array}$ & Ministry of Foreign Affairs, NL \\
\hline Bärbel Weiligmann & Senior Advisor, Workforce Nutrition & GAIN \\
\hline Barlatey Saliha & Head of Corporate Industry Affairs & Nestle S.A. \\
\hline Ben Valk & Lead Food \& Agri Partnerships & Rabobank \\
\hline Bernadette Gutmann & Child Rights \& Business Specialist & UNICEF \\
\hline Birgitta Tazelaar & $\begin{array}{l}\text { Deputy Director-General for International } \\
\text { Cooperation, Ministry of Foreign Affairs, NL }\end{array}$ & \\
\hline Breda Gavin-Smith & Global Public Health Nutrition Manager & Sight and Life \\
\hline Camilla De Nardi & Associate FReSH & WBCSD \\
\hline Candela Fito & Junior Associate & GAIN \\
\hline Carola van Rijnsoever & $\begin{array}{l}\text { Director of Inclusive Green Growth } \\
\text { Department and Ambassador for } \\
\text { Sustainable Development }\end{array}$ & Ministry of Foreign Affairs, NL \\
\hline Catherine Gee & Head of Development Office & GAIN \\
\hline Chaouki Fadoi & Nutrition Policy Officer & European Commission - DEVCO \\
\hline Chavanne Hanson & $\begin{array}{l}\text { Food Choice Architecture and Nutrition } \\
\text { Manager }\end{array}$ & Google \\
\hline Chris Osa Isokpunwu & Head of Nutrition & Federal Ministry of Health, Nigeria \\
\hline Cindy van den Boom & Senior Policy Officer & Ministry of Foreign Affairs, NL \\
\hline Cornelia Richter & Vice-President / Chair & $\begin{array}{l}\text { IFAD / UN Standing Committee on } \\
\text { Nutrition }\end{array}$ \\
\hline
\end{tabular}




\begin{tabular}{|c|c|c|}
\hline Darren Welch & Head of Policy & DFID \\
\hline Diane Holdorf & Managing Director & WBCSD \\
\hline Dominic O'Neill & Chief Operating Officer & World Wide Fund for Nature International \\
\hline Doreen Hashemi & Private Sector Development Adviser & $\begin{array}{l}\text { UK Department for International } \\
\text { Development }\end{array}$ \\
\hline Elizabeth Maddison & Director, Strategic Operations & GAIN \\
\hline Els de Groene & $\begin{array}{l}\text { Global Director Nutrition Standards \& } \\
\text { Advocacy }\end{array}$ & Unilever \\
\hline Erik Lauret & Responsible Retailing Coordinator & SPAR International \\
\hline Estefania Marti Malvido & & ATNI \\
\hline Faustine Lescanne & PlumpyField Director & Nutriset Group \\
\hline Felia Salim & $\begin{array}{l}\text { Chairperson of the Governing Board of } \\
\text { Kemitraan / Partnership for Governance } \\
\text { Reform and the Chairperson of } \\
\text { Transparency International Indonesia }\end{array}$ & GAIN \\
\hline Ferew Lemma & Public Health Specialist and Nutritionist & Ministry of Health Ethiopia \\
\hline Fiona Kirk & Junior Communications Manager & Access to Nutrition \\
\hline Firas Zuhairi & Head of IT & GAIN \\
\hline Fokko Wientjes & $\begin{array}{l}\text { Vice-President Malnutrition Programs and } \\
\text { Partnerships }\end{array}$ & Royal DSM \\
\hline Frank Mechielsen & Senior Program Manager Sustainable Diets & Hivos \\
\hline Frits van der Wal & $\begin{array}{l}\text { Senior Policy Advisor Food and Nutrition } \\
\text { Security }\end{array}$ & Ministry of Foreign Affairs, NL \\
\hline Gael Lescornec & Program Manager & IDH - The Sustainable Trade Initiative \\
\hline Gerda Verburg & UN ASG and Coordinator & Scaling Up Nutrition (SUN) Movement \\
\hline Guillaume Taylor & Co-founder and Managing Partner & Quadia \\
\hline Heleen Bos & $\begin{array}{l}\text { Foreign Development Projects/Specialist } \\
\text { Organics }\end{array}$ & Rijk Zwaan \\
\hline Heloise Troc & & European Commission \\
\hline Herbert Smorenburg & & $\begin{array}{l}\text { Netherlands Working Group on } \\
\text { international Nutrition }\end{array}$ \\
\hline Hilina Belete Beyene & General Manager & Hilina Enriched Foods PLC \\
\hline Hisayuki Uneyama & Executive Specialist & Ajinomoto Co., Inc. \\
\hline Ichiro Nishikura & $\begin{array}{l}\text { General Manager, Nutrition Improvement } \\
\text { Dept. }\end{array}$ & Ajinomoto Co., Inc. \\
\hline Ido Verhagen & & World Benchmarking Alliance \\
\hline Inge Kauer & Executive Director & Access to Nutrition Foundation \\
\hline Isabelle Grosmaitre & Alimentation Initiative catalyst & DANONE \\
\hline Ismael Barmou & General Manager & $\begin{array}{l}\text { STA - Societe de Transformation } \\
\text { Alimentaire }\end{array}$ \\
\hline Jacobine Das Gupta & Director Sustainability - Lead Nutrition & DSM \\
\hline Jacqui Stephenson & Global Responsible Marketing Officer & Mars \\
\hline Jan Cherim & Managing Director & SEAF - Small Enterprise Assistance Funds \\
\hline Japo Ouwerkerk & Director Public Policy \& Government Affairs & PepsiCo \\
\hline Jeffrey Misomali & Associate Director- Investments & The Power of Nutrition \\
\hline Jonathan Tench & SUN Business Network Coordinator & GAIN \\
\hline Joost Gorter & Director & NewForesight \\
\hline Judith Smit & Global Lead Rice Fortification & DSM \\
\hline Kameswar Ellajosyula & Global Head Innovation & Olam International \\
\hline
\end{tabular}




\begin{tabular}{|c|c|c|}
\hline Kaosar Afsana & Director Health, Nutrition \& Population & BRAC University \\
\hline Karl Deering & Senior Technical Advisor, Partnerships and & CARE International \\
\hline Katharina Krumbiegel & Adviser to the Vice-President & IFAD \\
\hline Katherine Richards & Head of Hunger and Nutrition & Save the Children UK \\
\hline Kathryn Dewey & Professor Emerita & University of California, Davis \\
\hline Katrijn Otten & Director Policy and Government Relations & Cargill \\
\hline Kazi Russel Pervez & Counsellor & Embassy of Bangladesh, The Hague \\
\hline Kazuko Suzuki & Secretary General & $\begin{array}{l}\text { Japanese Chamber of Commerce and } \\
\text { Industry in the Netherlands (JCC) }\end{array}$ \\
\hline Kedar Mankad & Program Officer & Bill \& Melinda Gates Foundation \\
\hline Kerri Wazny & Foresight Project Manager & $\begin{array}{l}\text { Global Panel on Agriculture and Food } \\
\text { Systems for Nutrition }\end{array}$ \\
\hline Khizer Alam Khan & CEO & $\begin{array}{l}\text { Switch Communications \& Bakhabar } \\
\text { Kissan }\end{array}$ \\
\hline $\begin{array}{l}\text { Khondaker Ehteshamul } \\
\text { Kabir }\end{array}$ & Counsellor & Embassy of Bangladesh, The Hague \\
\hline Kim van Seeters & Senior Policy Officer & $\begin{array}{l}\text { Ministry of Agriculture, Nature and Food } \\
\text { Quality, NL }\end{array}$ \\
\hline Klaus Kraemer & Managing Director & Sight and Life Foundation \\
\hline Kristin Hall & Partnerships \& Engagement & $\begin{array}{l}\text { Global Panel on Agriculture and Food } \\
\text { Systems for Nutrition }\end{array}$ \\
\hline Kristin Sundell & Senior Advocacy Specialist & GAIN \\
\hline Lauren Ruth Landis & Director Nutrition & World Food Programme (WFP) \\
\hline Laurence Rycken & $\begin{array}{l}\text { Scientific and Standards Programme } \\
\text { Manager }\end{array}$ & International Dairy Federation \\
\hline Laurene Aubert & Senior Associate for Global Partnerships & GAIN/SBN \\
\hline Lawrence Haddad & Executive Director & GAIN \\
\hline Leonard Mizzi & Head of Unit & European Commission \\
\hline Leonie Barelds & Senior Advisor Child Rights and Business & UNICEF \\
\hline Lina Mahy & Technical Officer & World Health Organization \\
\hline Louise O. Fresco & President & Wageningen University \& Research \\
\hline Luisa Volpe & Head of Policy Development & World Farmers' Organisation, WFO \\
\hline Luuk-Jan Boon & Managing Director & BoPInc \\
\hline Lynnette Neufeld & Director, Knowledge Leadership & GAIN \\
\hline Maaike Groot & Manager Public Affairs & East-West Seed \\
\hline Maaike Bruins & Senior Scientist Nutrition & DSM \\
\hline Manasi Sachin Deodhar & Manager & Ajinomoto Co. Inc. \\
\hline Maria Kasparian & Executive Director & Edesia \\
\hline Mariëlle de Jonge & Associate GAIN NL & GAIN \\
\hline Marije Boomsma & Consultant Sustainable Business Coalitions & World Food Program Myanmar \\
\hline Marinka van der Hoeven & Assistant Professor & $\begin{array}{l}\text { Amsterdam Centre for World Food } \\
\text { Studies and Infectious disease \& Nutrition } \\
\text { - VU University }\end{array}$ \\
\hline Mariska Dotsch-Klerk & Global Manager Sustainable Nutrition & Unilever R\&D Vlaardingen \\
\hline Mark Wijne & Senior program Manager & Access to Nutrition Foundation \\
\hline Mauricio Adade & President & Latin America, Royal DSM \\
\hline Max Hall & & WEF \\
\hline Md Ruhul Amin Talukder & Joint Secretary & $\begin{array}{l}\text { Ministry of Agriculture, Govt. of } \\
\text { Bangladesh }\end{array}$ \\
\hline
\end{tabular}




\begin{tabular}{|c|c|c|}
\hline Melissa Pinfield & $\begin{array}{l}\text { Programme Director, Food and Land Use } \\
\text { Coalition }\end{array}$ & SYSTEMIQ \\
\hline Mieke van Reenen & Manager GAIN NL & GAIN \\
\hline Mika Bogers-Hosoe & Office \& Finance Assistant & GAIN \\
\hline Mikaela d'Angelo & Senior Account Executive & Edelman \\
\hline Mikio Aoki & $\begin{array}{l}\text { Director, Commerce and Service Industry } \\
\text { Policy Group }\end{array}$ & $\begin{array}{l}\text { Ministry of Economy, Trade and Industry } \\
\text { of Japan }\end{array}$ \\
\hline Myrtille Danse & Director Latin America \& Caribbean & Hivos \\
\hline Nancy K. Martin & CEO/Founder & Fortify \\
\hline Nicolas Gausseres & Chief Alimentation Science Officer & DANONE \\
\hline Nicole Metz & Senior Knowledge Broker & Food \& Business Knowledge Platform \\
\hline Ninja Lacey & Intern & Ministry of Foreign Affairs, NL \\
\hline Paul van der Logt & Head of Food Nutrition Security & Ministry of Foreign Affairs, NL \\
\hline Paul Vos & Senior Research Manager & Access to Nutrition Initiative \\
\hline Paul Young & Chief Financial Officer & GAIN \\
\hline Penjani Mkambula & Programme Lead, Food Fortification & GAIN \\
\hline Penny van der Kaars & Communications Manager & SPAR International \\
\hline Peter van der Werf & Director, Active Ownership & Robeco \\
\hline Petra Klassen Wigger & Head of Nutrition, Health and Wellness Unit & Nestle Research \\
\hline $\begin{array}{l}\text { Princess Viktoria de } \\
\text { Bourbon de Parme }\end{array}$ & & Save the Children, Netherlands \\
\hline Rachel Mulrenan & Campaigns Adviser & Changing Markets Foundation \\
\hline Rachel Thompson & Policy Fellow & World Obesity \\
\hline Rebecca Egan & Senior Nutrition Advisor & USAID \\
\hline Rekha Lecomte & Regional Director for India \& South Asia & Nutriset \\
\hline Rocco Renaldi & Secretary General & International Food and Beverage Alliance \\
\hline Rona Weekes & $\begin{array}{l}\text { Global Marketing Director Nutrition } \\
\text { Improvement }\end{array}$ & DSM \\
\hline Ruerd Ruben & Senior Researcher & Wageningen University \& Research \\
\hline Saliha Barlatey & Head of Corporate Industry Affairs & Nestle S.A. \\
\hline Sandra Ederveen & Associate, Development Office & GAIN \\
\hline Sarah Cummings & $\begin{array}{l}\text { Public-Private Partnership and Research } \\
\text { Uptake Expert }\end{array}$ & Wageningen University \& Research \\
\hline Sarah Gibson & Programme Officer & Children's Investment Fund Foundation \\
\hline Sarah Roberts & CEO & Ethical Tea Partnership \\
\hline Saskia de Pee & Senior Technical Advisor - Nutrition & UN World Food Programme \\
\hline Saskia Osendarp & Executive Director & Micronutrient Forum \\
\hline Saul Morris & Director, Programme Services & GAIN \\
\hline Sean de Cleene & $\begin{array}{l}\text { Head of Food System Initiative and } \\
\text { Member of the Executive Committee }\end{array}$ & World Economic Forum \\
\hline Shawn Baker & Director, Nutrition & Bill \& Melinda Gates Foundation \\
\hline Sheikh Mohammed Belal & Ambassador & Embassy of Bangladesh, The Hague \\
\hline Sofia Condes & Nutrition Finance Lead & GAIN \\
\hline Sonja Timmer & Investment / Project Officer & Common Fund for Commodities (CFC) \\
\hline Stanley Zlotkin & Chief, Centre for Global Child Health & The Hospital for Sick Children \\
\hline Steve Godfrey & Director, Policy and External Relations & GAIN \\
\hline Steven Bartholomeusz & Policy Director & Food Industry Asia \\
\hline
\end{tabular}




\begin{tabular}{|c|c|c|}
\hline Stineke Oenema & UNSCN Coordinator & $\begin{array}{l}\text { UN System Standing Committee on } \\
\text { Nutrition }\end{array}$ \\
\hline Sudhvir Singh & Director of Policy & EAT \\
\hline Sufia Askari & Director, Child Health \& Development & Children's Investment Fund Foundation \\
\hline Terumi Onuma & Advocacy Officer & Save the Children Japan \\
\hline Tobias Wasmuht & CEO & SPAR International \\
\hline Toine Timmermans & & Wageningen University \& Research \\
\hline Toko Kato & Nutrition \& Food Systems Officer & UN FAO \\
\hline Tom Arnold & Member of the Board & GAIN \\
\hline Vanessa Melani Adams & Vice President & $\begin{array}{l}\text { Alliance for a Green Revolution in Africa- } \\
\text { AGRA }\end{array}$ \\
\hline Viola Heeneman & Corporate Partnerships Manager & UNICEF \\
\hline Visala James & Global Value Chain Head & Syngenta \\
\hline Wenneke Bosshardt & Project Advisor & RVO \\
\hline Yoshiko Kijima & $\begin{array}{l}\text { Minister of the Embassy of Japan in the } \\
\text { Netherlands }\end{array}$ & \\
\hline Yumiko Horie & Advocacy Manager & Save the Children Japan \\
\hline Yvonne Bakken & Public Private Partnerships Manager & DSM \\
\hline
\end{tabular}

\section{VIDEO}

Video of The Hague conference at https://www.youtube.com/watch?v=IwZpviKit6o 